Session 2121

\title{
K'NEXERCISE: INTRODUCING STUDENTS TO THE KEY PARTICIPANTS IN THE DESIGN-CONSTRUCTION PROCESS
}

\author{
Allen C. Estes, Eric M. Lachance, and Stephen J. Ressler \\ United States Military Academy
}

\begin{abstract}
The design-construction process is complex and involves key players who must communicate and work together for a project to be successful. The owner, architect, project manager, construction contractor, sub-contractors, vendors, and lawyers all have key roles, unique perspectives, individual motivations and vested (but sometimes competing) interests in a given project. Without first-hand experience, students can have difficulty understanding how the parties interact and why conflicts or disputes arise. This paper describes a participative hands-on construction management exercise which models the design-construction process using K'nex, ${ }^{\circledR}$ building toys and provides assessments gained from four consecutive years of experience with senior level CE students.
\end{abstract}

Student teams are divided into Architect-Engineering firms, construction contractors, and project managers. The A-E firms design competing structures that meet specific functional requirements using K'nex components. Construction contractors, who want to win the job while maximizing their profit, use the A-E's design documents to prepare a competitive bid. Students construct the competing structures as a timed event and the total cost is based on materials, labor, and bonuses/penalties. The winning project provides a functional structure for the owner at the lowest cost. Individual participants are graded on how well they served their own interests in the free-market economy by maximizing profit, reducing errors, cutting costs, etc.

Assessments show that students developed keen insight into the roles, motivations, and interactions of the key participants as a result. The exchanges were lively, emotional, and sometimes contentious. The rules can be modified to include litigation, quality control, cash flow, or most other aspects of the complex design-construction process. Students competed in a K'nexercise at the ASCE Regional Student Conference at West Point in April 2001. Due to the success of the competition, the K'nexercise will be an official event at the ASCE Student National Conference in Madison in June 2002.

\section{INTRODUCTION}

The design and construction of a project is a long and complex process that students do not fully appreciate until they are involved on their first job site. For an employer, this is not the appropriate time for a young employee to learn the process and the players. Each participant in the design-construction process has interests and motivations that govern their behavior in the marketplace. The K'nexercise used at the United States Military Academy helps students experience these perspectives first-hand. The students receive instruction on the design-

"Proceedings of the 2002 American Society for Engineering Education Annual Conference \& Exposition Copyright (C) 2002, American Society for Engineering Education" 
construction process in the senior seminar and the construction management courses. The $\mathrm{K}$ 'nexercise ties this instruction together.

The K'nexercise is a role-playing game where students are formed into groups and are responsible for the design and/or the construction of a structure. The design-construction team as shown in Figure 1 follows the American Society of Civil Engineers model ${ }^{1}$. The exercise attempts to replicate the U.S. Army Corps of Engineers process ${ }^{2}$ (Figure 2), from the engineer teams taking an owner's requirements through design, bidding, construction and finally inspection and acceptance. This paper describes the organization and operation of the exercise and presents student feedback on the experience.

\section{K'NEX SITUATION}

The exercise is divided into three phases: (1) Design and Bid Preparation, (2) Design Closeout and Contract Award, and (3) Construction. All students have a role in each phase. The students are broken into three groups: the Architect-Engineer Firm (A-E), the Project Manager (PM) and the Contractor. Depending on the size of the class or event, there is one PM and four Contractors for each A-E. Each group has different responsibilities but share the common goal of owner satisfaction.

\section{Architect-Engineer:}

1. Responsible for the design and initial estimate of the structure for the owner.

2. Respond to any comments from the Project Managers review of the plans and specifications. Respond to any Request for Information (RFI) or Requests for Contract Modifications from the contractors.

3. Observe construction and respond to any construction claims.

\section{Project Manager:}

1. Act as the owner's representative.

2. Review the plans and specifications to ensure they meet owner's intent.

3. Rapidly process RFIs and Contract Modifications for the contractors.

4. Observe construction and conduct final quality assurance inspections. Turn the project over to the owner for load testing.

\section{Contractor:}

1. Responsible for constructing the structure.

2. Receive Plans and Specifications and prepare a competitive construction bid.

3. Submit bid, RFIs and Request for Contract Modifications. Order all materials for construction

4. Layout and build the project. Turnover structure to Project Manager for approval and process any claims.

Every student receives a grade on the exercise based on the group's ability to "win" in the exercise and on their individual success as a contractor, A-E, or PM. For example, the contractor is rewarded both for obtaining a low bid and on achieving a reasonable profit. The A-E's final score comes from producing a design that is under the project budget, costs less than the 
competing A-E firms, and results in a contractor low bid that is less than the A-E estimated cost. The PM is graded on the conduct of the bid opening, finding design errors, controlling the construction process, and turning a deficiency-free project over to the owner.

\section{EXERCISE ACTIVITIES}

\section{Phase I: Design and Bid Preparation}

The K'nexercise starts with the design phase. The A-E group is given a project scope and uses their creativity and engineering fundamentals to create a design that meets the owner's intent. The drawing in Figure 3 shows the 2001 project which is a pedestrian bridge over a roadway. The required spans, minimum heights, and other constraints are specified in the project description. The structure must be constructed with K'nex building toys. ${ }^{3}$ The K'nex set consists of multi-colored plastic rods of varying lengths and a variety of connector pieces. This modern-day version of Tinker-toys or Lincoln logs allows one to connect pieces and build a variety of structures. The A-E group is given a K'nex set to assist with their design. The assumption is if the students were designing a real structure, they would have appropriate software to assist in the analysis/design. A working design is critical; however, it is usually not the only driving force for the engineer. The A-E team must produce a set of drawings and specifications that the PM and contractor will be able to understand and use. Figures 4 and 5 show samples of such plans done by cadet A-E teams.

The A-E group must also complete a cost estimate. The estimate includes the material and labor costs and the A-E team is given a Cost Estimate Worksheet (Figure 6) to assist them. Labor cost is based on the estimated construction time (in seconds) and the crew size. Once the estimate and design are complete, they are given to the PM for review.

The design is evaluated by the PM and Owner on four areas:

Biddability - The plans and specs must be sufficiently complete for the Contractors to prepare accurate bids for the project and the estimate must be under a certain cost amount.

Constructibility - The structure must be buildable exactly as depicted it in the plans and specifications.

Operability - The structure must satisfy all of the design requirements.

Aesthetics - The structure should conform to the Owner's stated requirements for physical appearance.

Once the plans and specifications are reviewed by the PM, he or she gives a set to each contractor bidding the work. The contractors use pricing data from four vendors to determine the total cost of the project. The vendors' prices are conditional on size of purchase, etc, to force the contractors to conduct some price analysis in order to get the low bid. If the contractors have questions, they can send up an RFI through the PM to the A-E. It is the A-E's responsibility to respond in a timely fashion and if they do not, they are penalized.

"Proceedings of the 2002 American Society for Engineering Education Annual Conference \& Exposition Copyright (C) 2002, American Society for Engineering Education" 


\section{Phase II: Design Closeout and Contract Award}

The second phase completes the design portion of the K'nexercise. The A-E evaluates the PM comments and adjusts their plan to meet the owner's intent. Once the A-E and PM reconcile all the comments, the PM will give an update to the Contractors. Contractors complete and submit their bids and order materials.

If the contractors want to modify the design, the PM will evaluate the request for contract modification and forward it to the A-E. The A-E either approves or disapproves the modification and responds back with an explanation. If an approved contract modification reduces the cost of the project, the contractor is awarded $50 \%$ of the savings as a value-engineering bonus. Phase II ends with the bid opening. The bid opening is enhanced by last-minute sale prices from vendors which offers contractors the opportunity to modify their bids accordingly. The PM administers the event and publicly announces the lowest bidder.

\section{Phase III: Construction}

The contractors decide on the size of their labor forces and inventory materials prior to construction. Contractors carefully prepare their job sites by laying out materials, but cannot pre-assemble any pieces. Construction begins and the PM keeps the time. The game clock continues until the contractor declares the job complete. Once the PM starts the clock, the contractor can order any materials left out or additional materials required to make the design work as construction issues arise. One team member must fill out an order form and take it to the instructor to get the missing/additional materials. This step adds to the total project cost, much like in the real world, in two ways. First, the contractor group member who is ordering materials is pulled away from the team's productivity, thereby adding labor cost. Second, the "During Construction" material cost is on average twenty percent higher than the material costs available during the bid portion.

Figure 7 shows a site layout and a project under construction. Once the contractor states construction is complete, the clock stops and the PM inspect the structure (Figure 8), comparing it to the plans and specifications. The PM may inspect the final structure, but is not allowed to load test it. If the PM finds the structure is not satisfactory, the contractor must make the necessary repairs as the PM restarts the game clock, adding more time to the labor cost. Once the PM approves the structure, it is turned over to the owner and load tested. For the exercise shown in Figure 9, the required load test was to support six AISC Steel Manuals for 30 seconds.

The K'nexercise ends with owners completing the grade sheets on all of the participants. Final scores are tallied and the results are posted. The instructor conducts an after-action review to discuss the lessons learned and students follow-up by submitting a written journal entry on the experience.

If the instructor wishes to add more realism, he or she can add claims and litigation to the process. The contractor submits a claim to the PM for additional money due to either a delay or poor information. The PM is the ruling authority on the claim. If the contractor disagrees, he can demand litigation or binding arbitration. An unbiased instructor acts as judge and jury and

"Proceedings of the 2002 American Society for Engineering Education Annual Conference \& Exposition Copyright (C) 2002, American Society for Engineering Education” 
decides the fate of the contractor's request. There can even be a penalty associated with filing frivolous litigation. An additional variation assigns students the role of K'nex vendors who establish the market price for materials. The vendors compete for contractor business and are graded solely on their profit. An even more advanced version of the exercise could introduced phased payments and create cash-flow challenges for the contractor.

\section{Assessment}

The United States Military Academy has conducted the K'nexercise for the past four

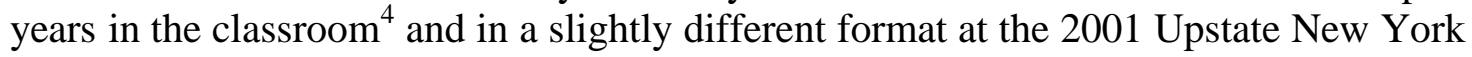
American Society of Civil Engineering Student Regional Conference. The feedback from all the participants demonstrates the importance of this exercise toward understanding the design construction process. Figure 10 shows the results from the course-end survey. The hands-on exercise reinforced the material taught in the professional practice seminar and construction management courses. Below are anecdotal comments taken from journal entries completed at the end of the exercise.

"Showed how if the players do not cooperate that the work will take forever to get done and the owner will get a poor product at best."

"Got to see the design construction process and how important coordination really is."

"I learned the responsibilities of each player with very little investment of out of class time."

"Really showed me how difficult it is to be the low bidder and still make a profit."

"I saw that it is important for all players to make a profit or the system breaks down."

"The PM is the owners representative and he must give the owner a structure that meets all of the owner's requirements."

"Really demonstrated how difficult the bidding process is for the contractor."

"This exercise was really fun!!”

\section{CONCLUSION}

The exercise had a real impact on the students. Not only does it reinforce their previous instruction on the design construction process but also it shows these young engineers the importance of cooperation, communication and negotiation. To top it off, the students really enjoyed the exercise.

\section{Bibliography}

1. American Society of Civil Engineers, Quality in the Constructed Product: A Guide for Owners, Designers and Constructors (ASCE Manual No. 73), ASCE, 1990.

2. U.S. Army Corps of Engineers, Washington D.C.

"Proceedings of the 2002 American Society for Engineering Education Annual Conference \& Exposition Copyright (C) 2002, American Society for Engineering Education" 
3. K'nex Instructions: Big Ball Factory, K'nex Industries Inc., Hatfield, PA, 1995.

4. Ressler, S., "The Project Management K'nexercise: Using Role-Playing to Facilitate Learning About Design and Construction," Proceedings, 1999 ASEE Annual Conference, ASEE, 1999.

\section{ALLEN C. ESTES}

Colonel Allen C. Estes is an Associate Professor and Civil Engineering Division Director at the United States Military Academy (USMA). He is a registered Professional Engineer in Virginia. COL Estes received a B.S. degree from USMA in 1978, M.S. degrees in Structural Engineering and in Construction Management from Stanford University in 1987 and a Ph.D. degree in Civil Engineering from the University of Colorado at Boulder in 1997.

\section{ERIC M. LACHANCE}

Major Eric Lachance is an instructor at the United States Military Academy. MAJ Lachance has taught Advanced Structural Analysis and Construction Management. He is the faculty advisor for the ASCE Student Chapter. MAJ Lachance received a BS degree in Construction Management from Arizona State University in 1990 and MS degrees from Stanford University in Civil Engineering, one in Structural Engineering and one in Construction Engineering.

\section{STEVEN J. RESSLER}

Colonel Steven J. Ressler is a Professor and Deputy Department Head for the Department of Civil and Mechanical Engineering at the United States Military Academy at West Point, NY. He is a registered Professional Engineer in Virginia. COL Ressler graduated from USMA with a B.S. degree in 1979. He obtained his M.S. degree and Ph.D. degrees from Lehigh University in 1989 and 1991, respectively. 


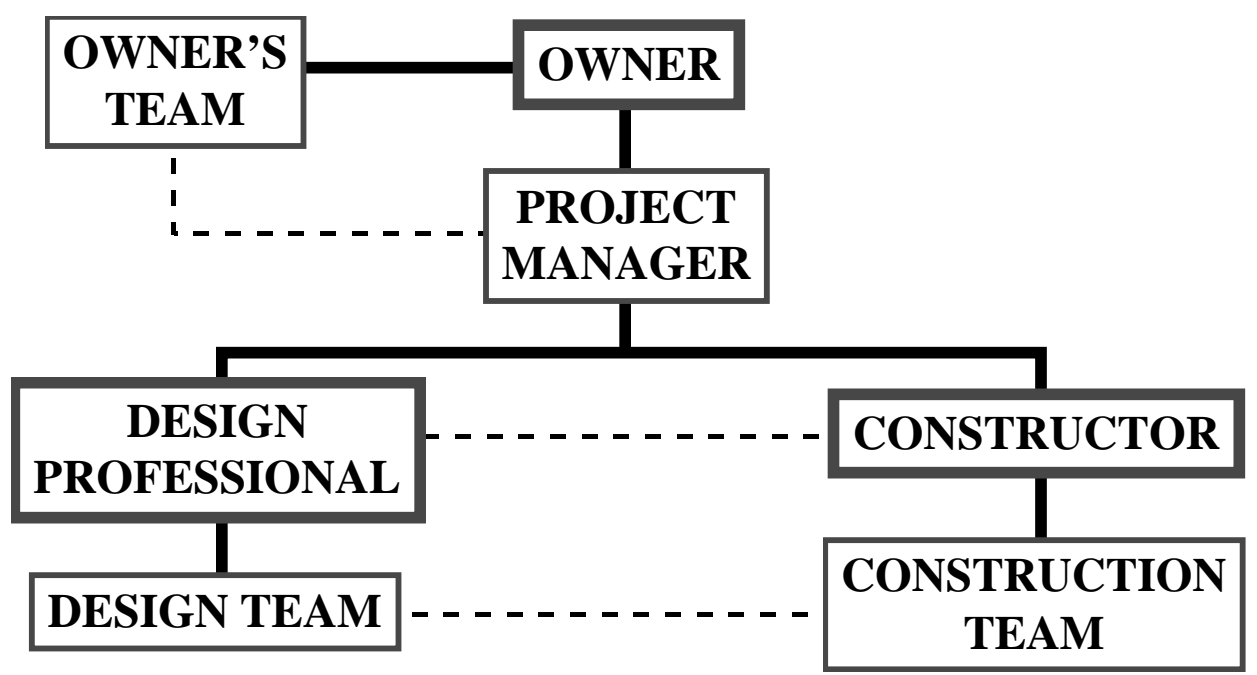

Figure 1: The ASCE Model of the Project Team

The U. S. Army Corps of Engineers Military Design and Construction Process

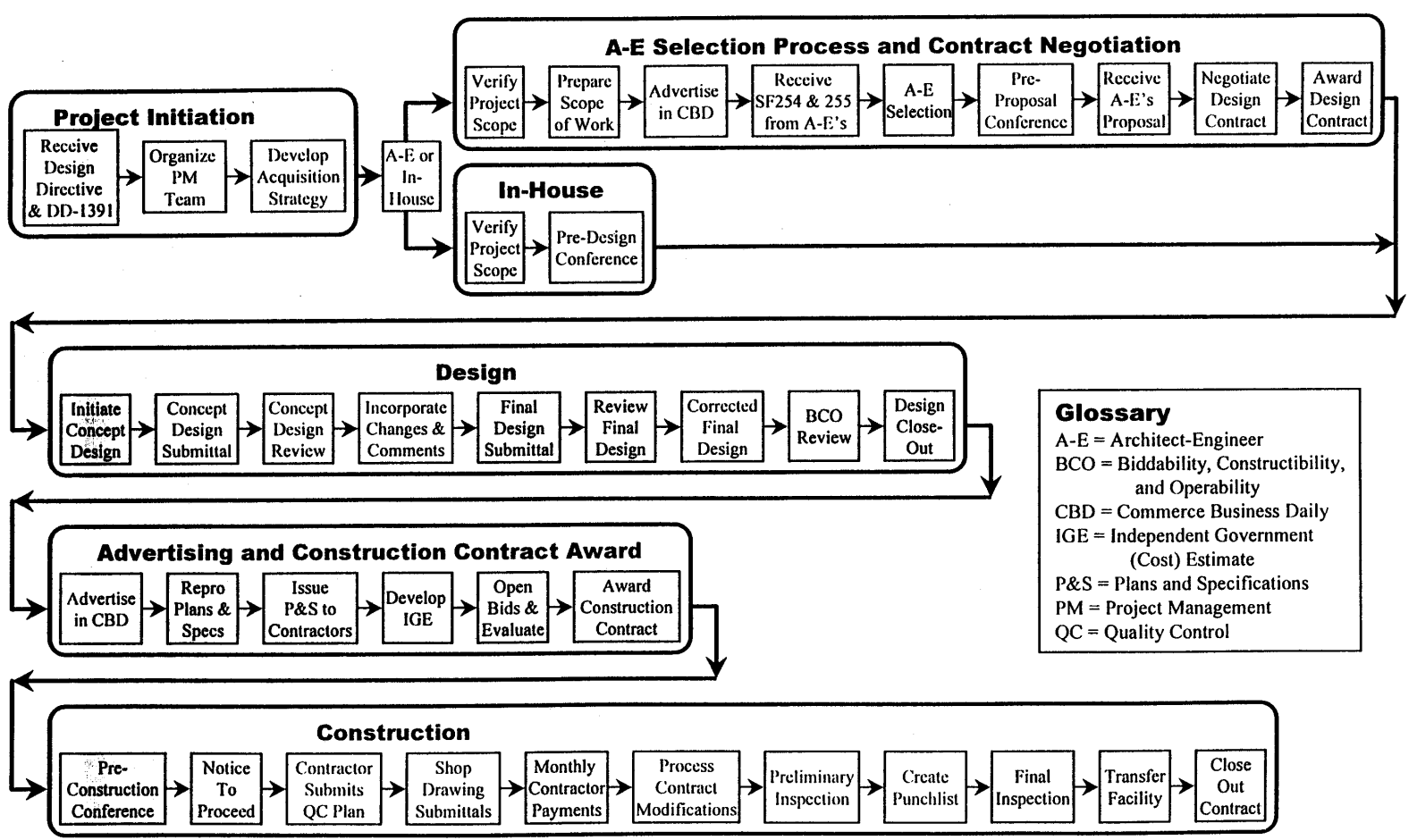

Figure 2: The U.S. Army Corps of Engineers Design and Construction Process that the K'nexercise Attempts to Replicate

"Proceedings of the 2002 American Society for Engineering Education Annual Conference \& Exposition Copyright (C) 2002, American Society for Engineering Education" 
Session 2121

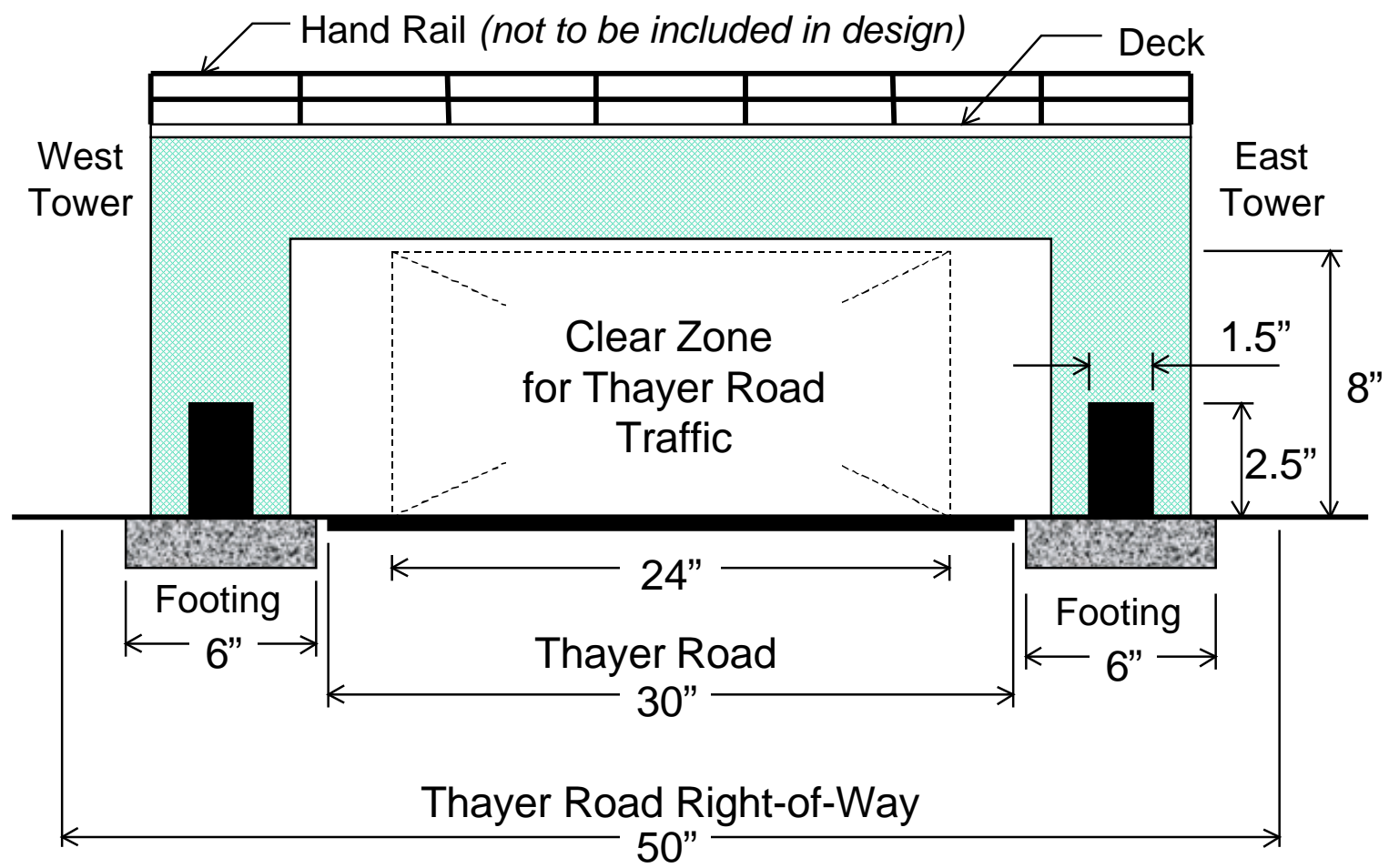

Figure 3: The Pedestrian Bridge Project Drawing for the 2001 K'nexercise

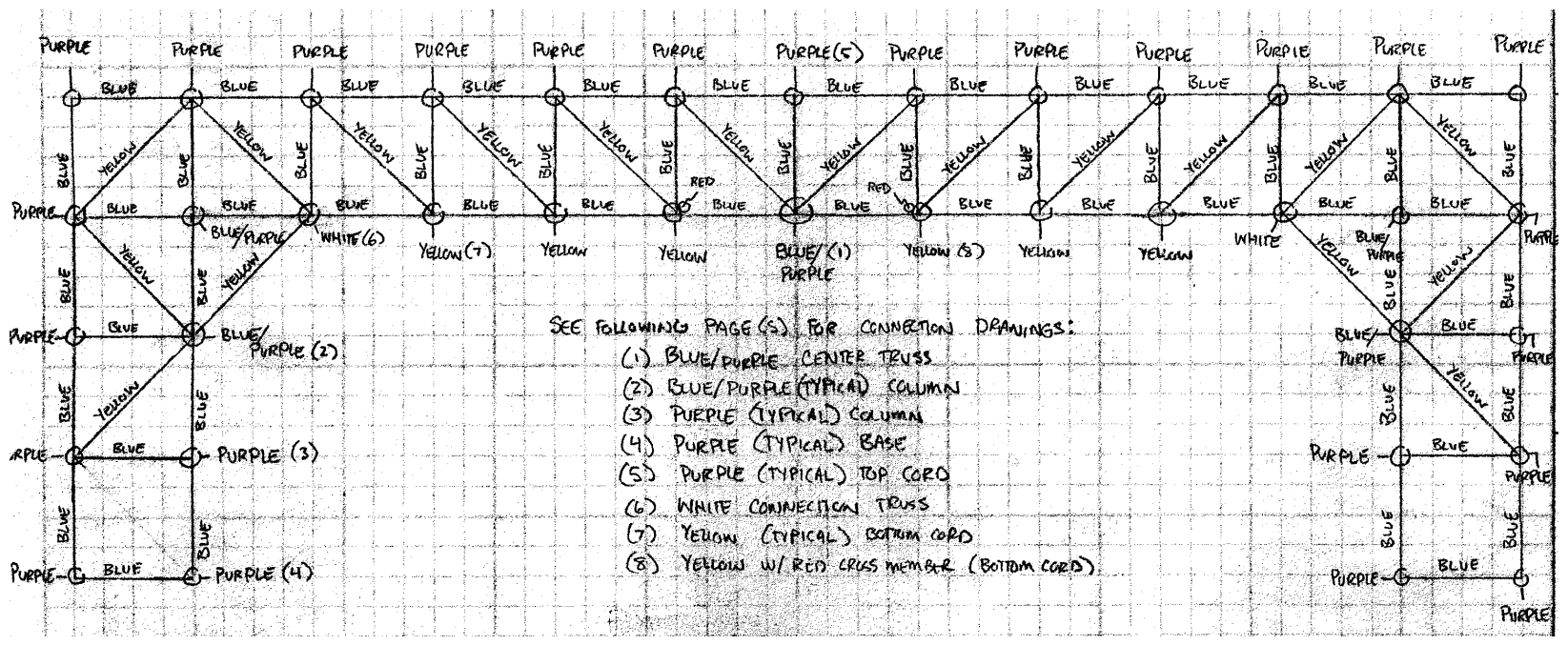

Figure 4: Sample Project Drawing Completed by one A-E Team in the 2001 K'nexercise

"Proceedings of the 2002 American Society for Engineering Education Annual Conference \& Exposition Copyright (C) 2002, American Society for Engineering Education" 


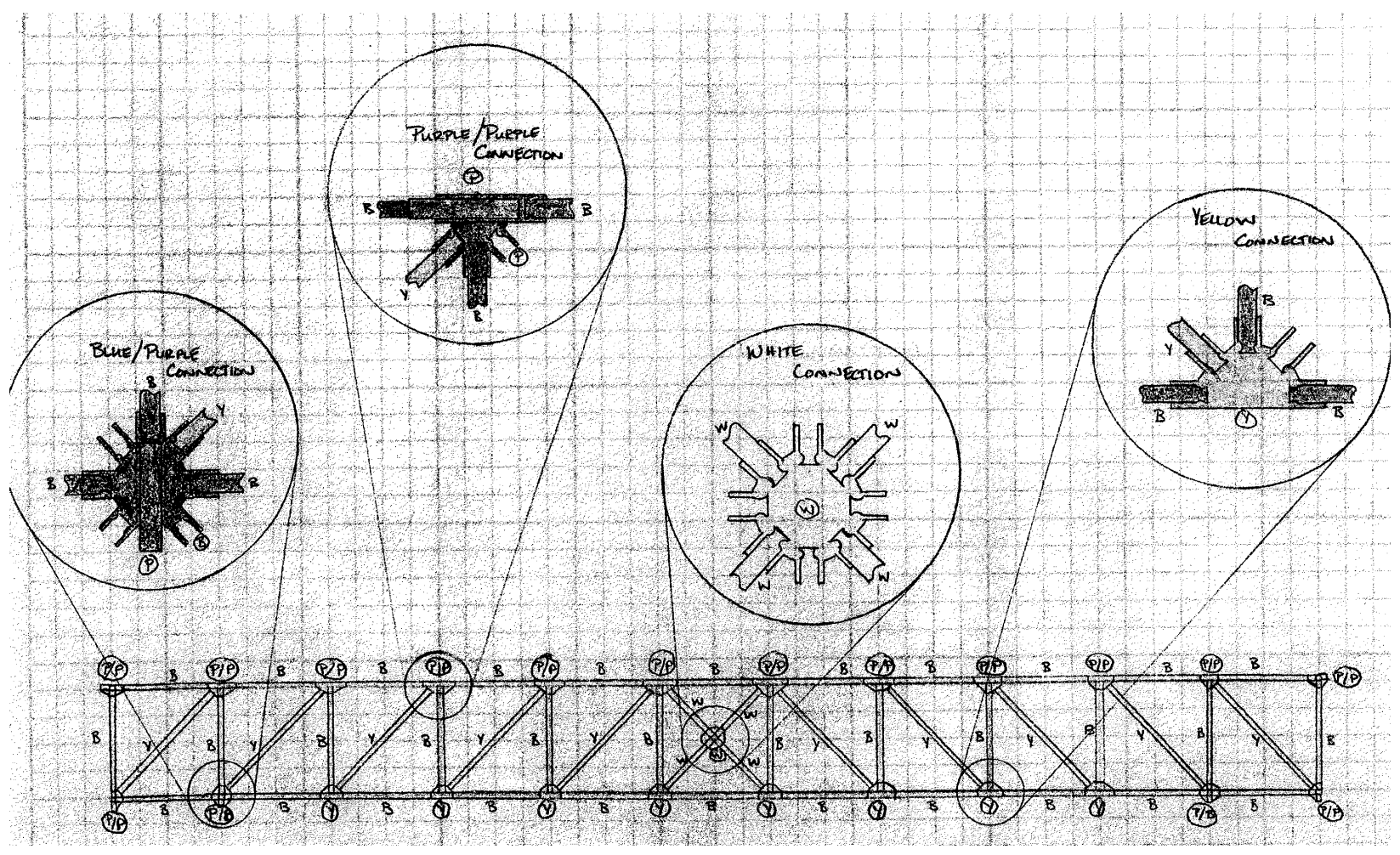

Figure 5: A Sample Drawing From a Second A-E Team: 2001 K'nexercise

\begin{tabular}{|c|c|c|c|}
\hline \multicolumn{3}{|c|}{ A/E COST ESTIMATE WORKSHEET } & \multirow[b]{3}{*}{$\begin{array}{l}\text { Total } \\
\text { Price }\end{array}$} \\
\hline Team Name & \multicolumn{2}{|c|}{ Date } & \\
\hline ITEM & $\begin{array}{l}* \text { Price } \\
\text { Each }\end{array}$ & $\begin{array}{l}\text { Number } \\
\text { Required }\end{array}$ & \\
\hline Green Rod (5/8") & $\$ 50$ & & \\
\hline White Rod (1-1/4") & $\$ 125$ & & \\
\hline Blue Rod $\left(2-1 / 8^{\prime \prime}\right)$ & $\$ 215$ & & \\
\hline Yellow Rod (3-3/8") & $\$ 340$ & & \\
\hline $\operatorname{Red} \operatorname{Rod}\left(5-1 / 8^{\prime \prime}\right)$ & $\$ 550$ & & \\
\hline Gray Rod (7-1/2") & $\$ 800$ & & \\
\hline Dark Gray Connector (1 socket) & $\$ 50$ & & \\
\hline Orange Connector ( 2 sockets) & $\$ 100$ & & \\
\hline Light Gray Connector (2 sockets) & $\$ 100$ & & \\
\hline Red Connector (3 sockets) & $\$ 150$ & & \\
\hline Green Connector (4 sockets) & $\$ 200$ & & \\
\hline Yellow Connector (5 sockets) & $\$ 250$ & & \\
\hline Light Orange Connector (5 sockets + Tab) & $\$ 300$ & & \\
\hline White Connector (8 sockets) & $\$ 350$ & & \\
\hline Purple Corner Connector (4 sockets) & $\$ 250$ & & \\
\hline Blue Corner Connector (7 sockets) & $\$ 350$ & & \\
\hline Rubber Bands & $\$ 5,000$ ea. & & \\
\hline Cable & $1,000 /$ in & & \\
\hline Counter Weight & $\$ 3,000 / \mathrm{lb}$ & & \\
\hline & Total Mat & rial Cost $=$ & \\
\hline $\begin{array}{l}\text { Labor Cost }=\text { Labor rate } \times \text { Est. Const } \\
=(\$ 10 / \text { second } / \text { person }) \times(\underbrace{}_{\text {Contract }} \text { se }\end{array}$ & $\begin{array}{l}\text { tion Time } x \\
\text { ads) x ( } \\
\text { s Overhead }\end{array}$ & $\begin{array}{l}\text { Crew Size } \\
\text { persons) }= \\
\text { \& Profit }=\end{array}$ & \\
\hline TOTAL ES & MATED & COST = & \\
\hline
\end{tabular}

Figure 6: Cost Estimate Worksheet

"Proceedings of the 2002 American Society for Engineering Education Annual Conference \& Exposition Copyright (C) 2002, American Society for Engineering Education" 
Session 2121

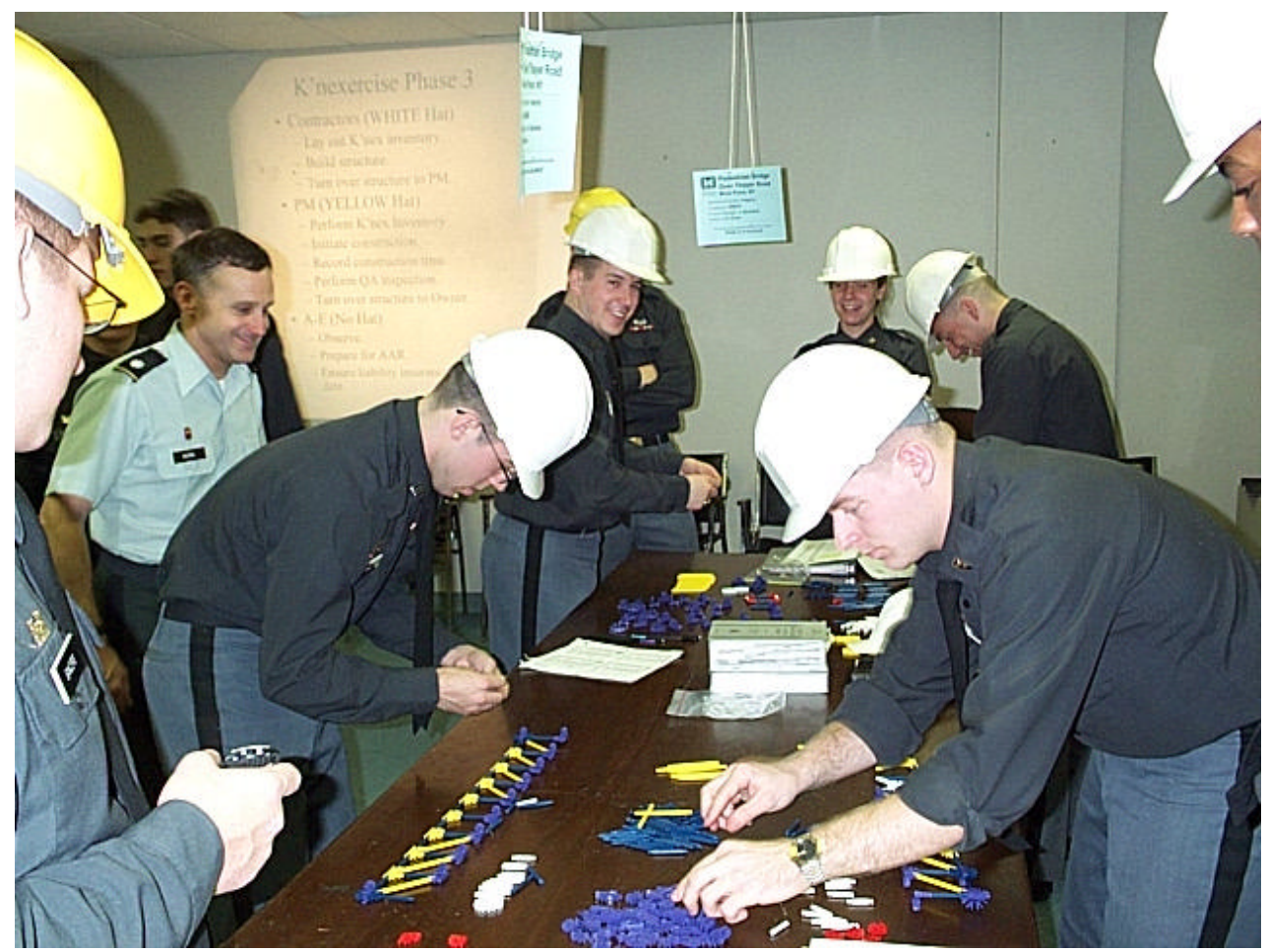

Figure 7: The Contractors Have Carefully Prepared Their Site and Assemble The Structure as Quickly as Possible

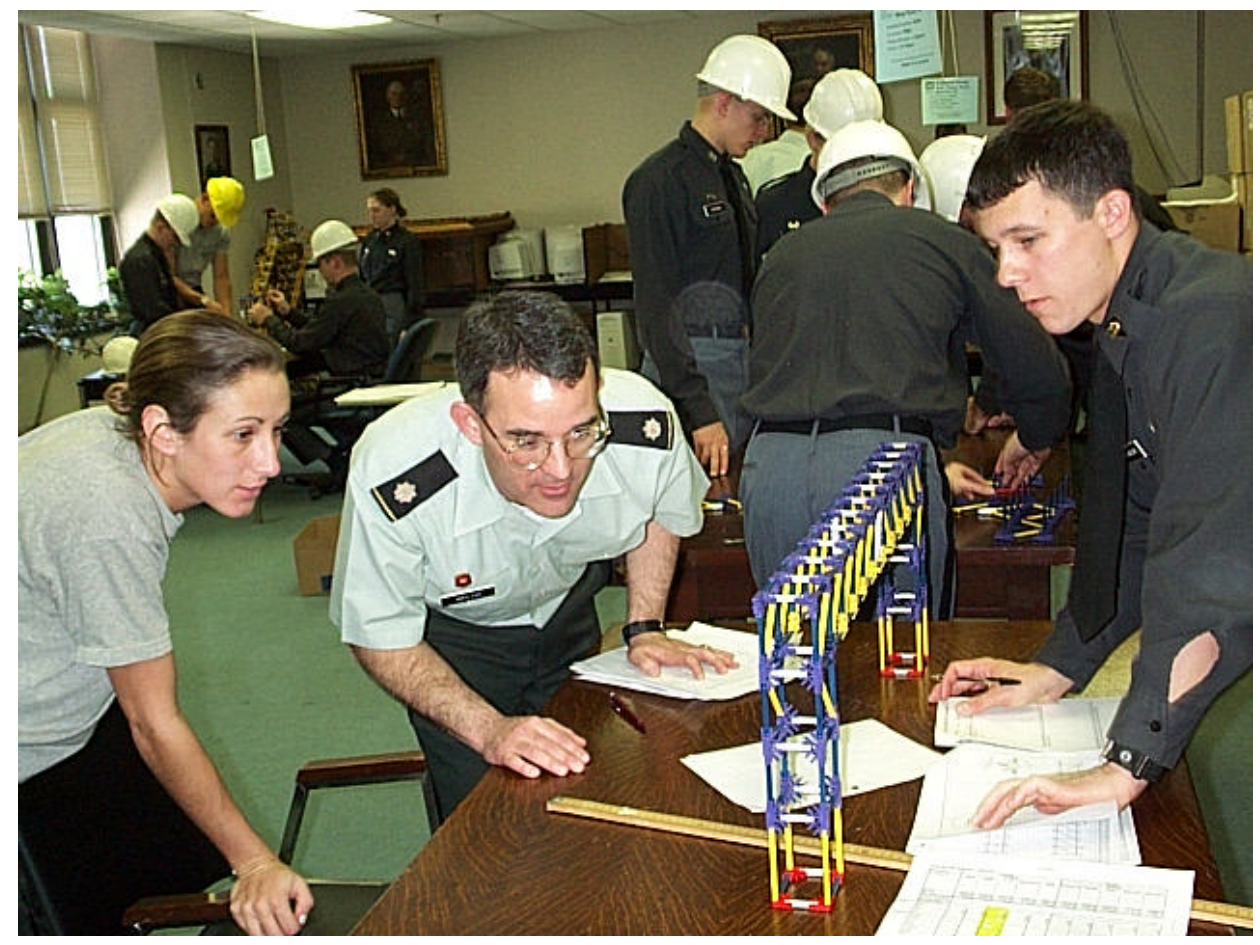

Figure 8: The Project Manager Inspects the Structure Before Turning it Over to the Owner (the Instructor)

"Proceedings of the 2002 American Society for Engineering Education Annual Conference \& Exposition Copyright (C) 2002, American Society for Engineering Education" 
Session 2121

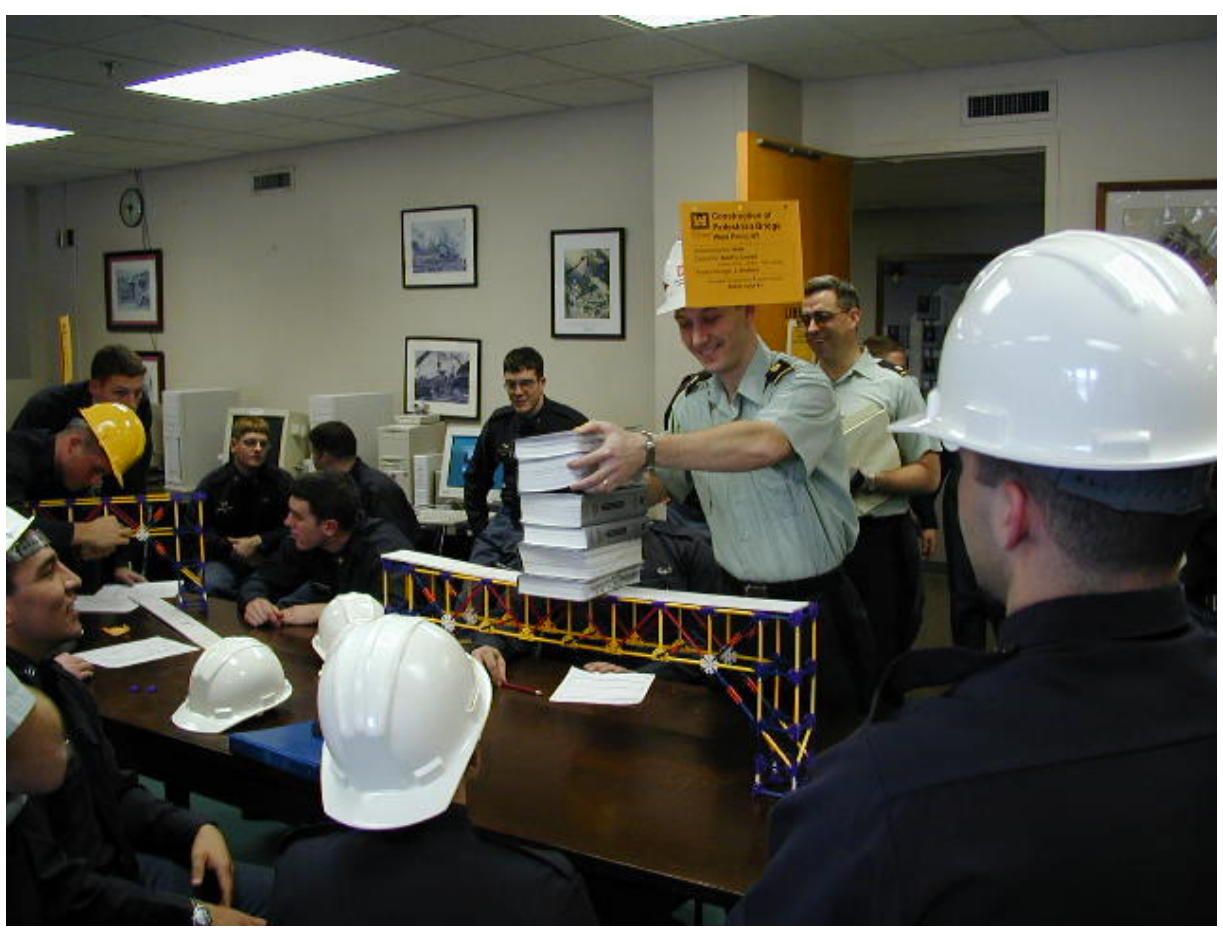

Figure 9: An Owner Load Tests the Completed Structure Using Six Steel Manuals

The Project Management K'nexercise contributed to my learning in this course.

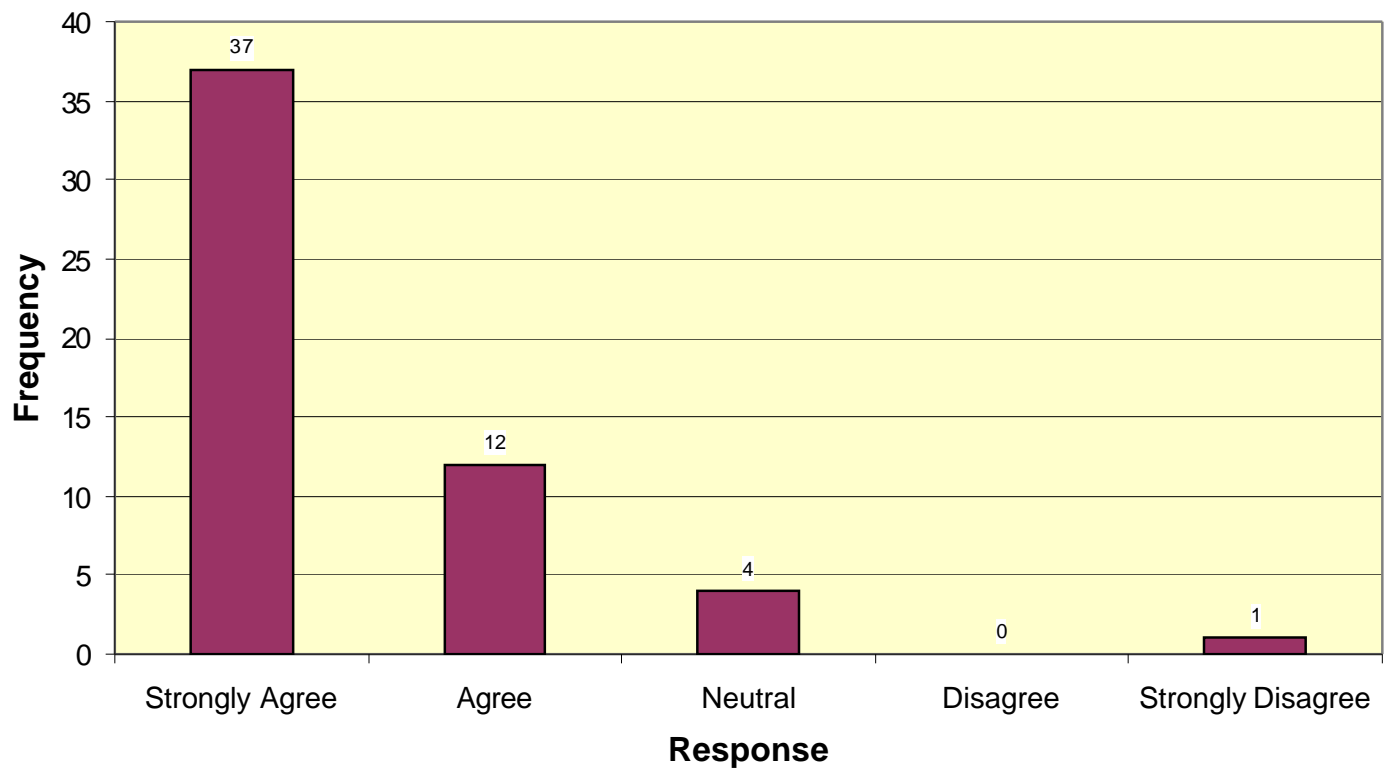

Figure 10: Results of 2001 Course-End Survey on Effectiveness of K'nexercise 